\title{
A sociologia da literatura de Lucien Goldmann
}

\section{CELSO FREDERICO}

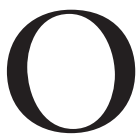

$S$ ESTUDOS LITERÁRIOS representam um momento importante na produção goldmanniana. As contribuições do autor para a sociologia da literatu-

ra são inegáveis e seus numerosos estudos particulares permanecem uma referência viva para os especialistas. Justamente nesse núcleo central da obra goldmanniana as questões metodológicas alçam o primeiro plano ${ }^{1}$.

O materialismo histórico ou o estruturalismo-genético (expressão que substitui a primeira nos textos da década de 1960) é considerado um "método geral" válido para todas as ciências humanas. A criação cultural e, especialmente, a literária, constitui um campo privilegiado de aplicação daquela metodologia.

Goldmann considera uma característica universal do comportamento humano a tendência à coerência. Os homens, perante os desafios colocados pela realidade exterior, procuram agir no sentido de interferir nos acontecimentos através de respostas às questões com que deparam. Esse empenho para adaptar-se à realidade segundo as conveniências humanas faz com que os indivíduos tendam a fazer de seu comportamento uma "estrutura significativa e coerente". Tal estrutura não é um dado atemporal, como no estruturalismo formalista. Há um processo prévio de elaboração, de gestação, de gênese das estruturas significativas. Além disso, a ação do homem modificando cotidianamente a realidade resulta em um processo contínuo de desestruturação das antigas estruturas e criação de novas. Com isso, o caráter significativo do comportamento humano, sua tendência natural à coerência, não é uma adequação mecânica às estruturas fixas, como pretendem os estruturalistas não-genéticos.

Por outro lado, a formação das estruturas significativas não deve ser considerada uma façanha individual. Elas, ao contrário, são o resultado complexo de um esforço coletivo, da ação das classes e grupos sociais que se constituem num processo amplo de relacionamento com o mundo, de adaptação e de respostas aos desafios da vida social.

A tendência à coerência e o caráter coletivo da elaboração das estruturas significativas já anunciam o caminho por onde irá trilhar a sociologia da literatura de Goldmann: as idéias piagetianas sobre a "assimilação" e "acomodação" do indivíduo ao meio social. Piaget desenvolveu uma elaborada teoria sobre a "natureza adaptativa da inteligência”. Segundo esse autor, o indivíduo, desde a infância, constrói suas estruturas mentais por meio da interação com o grupo social, num processo ininterrupto de acomodação e assimilação que conhece diversas 
fases, durante as quais ele assimila novas estruturas de percepção. Goldmann retoma o processo de construção das estruturas cognitivas para aplicá-lo às relações entre o autor e o grupo social. Aquele interage com o grupo social e procura responder às suas expectativas: a criação artística surge como uma resposta significativa e articulada, como expressão das possibilidades objetivas presentes no grupo social. Essa resposta significativa, segundo observou Sami Naïr,

funda o autor enquanto mediação constitutiva através da qual a consciência possível de um grupo se encarna de maneira coerente na obra literária. Inversamente, essa mediação constitutiva é o meio pelo qual o sujeito individual, imediatamente criador, entra em acomodação, em equilíbrio e assimila, sempre em sentido piagetiano, as categorias mentais possíveis do grupo, sujeito transindividual. Não há, portanto, homologia entre a estrutura biográfica ou sociológica do autor e aquela do grupo, mas entre as estruturas mentais categoriais da obra enquanto virtualidade daquelas do grupo ${ }^{2}$.

A aplicação do materialismo histórico no estudo da criação cultural em geral e da literatura em especial afirma a existência, nesses domínios, de uma coerência levada ao extremo que "se aproxima de um fim para o qual tendem todos os membros de um grupo social".

O ponto de partida de nosso autor é o Lukács de $A$ alma e as formas e $A$ teoria do romance. Essas obras, segundo Goldmann, marcam uma ruptura nos estudos de sociologia da literatura. Até então, os estudiosos consideravam a obra literária como um reflexo da realidade social, limitando-se a procurar uma correlação entre a obra e o conteúdo da consciência coletiva. Esse procedimento só é válido para as obras menores, aquelas que reproduzem a realidade social nos moldes do naturalismo, com exatidão de detalhes e pretensões de completa objetividade, mas cujo valor é meramente documental. Para as verdadeiras obras-primas, entretanto, em que a imaginação criadora dá altos vôos, esse método reducionista tem pouco a dizer.

O jovem Lukács subverteu essa perspectiva ao buscar uma nova correlação entre literatura e sociedade. Tal correlação não se dá mais no plano do conteúdo, mas da forma, da correspondência entre as categorias que estruturam a criação literária e a consciência coletiva. Essas categorias caracterizam-se basicamente por sua coerência, compreendida ainda de modo metafísico e a-histórico pelo Lukács de $A$ alma e as formas. Goldmann submete a forma a um tratamento historicista, aprofundando, nessa direção, as análises que já apareciam de modo incipiente em A teoria do romance.

A historicização da forma levou-o a substituir a vaga consciência coletiva por um novo sujeito, formado pelas condições históricas e sociais. Mas o sujeito, nas ciências humanas em geral, não deve ser concebido em rígida oposição ao objeto, como ocorre nas ciências naturais. O sujeito que observa a sociedade e reflete sobre ela, seja o cientista social ou o artista, faz parte dessa mesma sociedade. A reflexão, portanto, "não se faz do exterior, mas do interior da socieda- 
de". Por outro lado, a reflexão "é em grande medida organizada pelas categorias da sociedade", e o objeto estudado "é um elemento constitutivo, e mesmo um dos mais importantes, da estrutura do pensamento" 4 .

Quem é esse sujeito socialmente constituído cuja consciência é organizada pelas categorias da sociedade? Antes de ensaiar uma resposta, Goldmann procurou contrapor sua sociologia da literatura à psicanálise freudiana. Inicialmente, um elemento comum parece aproximar as duas disciplinas: ambas consideram o comportamento humano como dotado de um "fragmento de sentido" que se esclarece quando integrado no conjunto do qual faz parte. O comportamento, quando conectado a uma estrutura englobante, revela-se significativo. Essa estrutura, por sua vez, não é invariável: ela formou-se geneticamente e está em permanente mudança. Esses pontos coincidentes permitem que a sociologia goldmanniana e a psicanálise freudiana possam ser consideradas como pertencentes ao estruturalismo-genético.

As semelhanças, entretanto, param aí. $\mathrm{O}$ que separa as duas disciplinas é a questão do sujeito. A psicanálise, assim, como o cartesianismo, a fenomenologia e o empirismo, ficou restrita ao sujeito individual. Na psicanálise, esse sujeito é determinado pela biologia. Concebido, dessa forma, o sujeito vê a sociedade como um meio e os demais indivíduos como objetos, objetos de frustração, satisfação dos desejos ou obstáculos a eles.

Contra o culto do indivíduo, Goldmann elege como sujeito uma coletividade - o sujeito transindividual. Um exemplo recorrente através do qual Goldmann explica esse sujeito coletivo é a ação exercida por três indivíduos que carregam um piano. Quem é o sujeito da ação? Certamente, nenhum deles considerados separadamente e sim a realidade nova criada pela ação conjugada em que cada um dos participantes é parte integrante do verdadeiro sujeito da ação. Estamos aí perante um conjunto, perante relações intrasubjetivas que envolvem os participantes e que os transcendem. A participação consciente do indivíduo, sua imersão na atividade comum, distingue a concepção goldmanniana da "consciência coletiva" de Durkheim - um consciência exterior aos indivíduos e que se volta contra eles para integrá-los coercitivamente nas engrenagens sociais.

O exemplo dos três homens que carregam o piano é ilustrativo da existência de um sujeito coletivo, e isso vale para todo pensamento e ação social e cultural. $\mathrm{O}$ estudo da literatura não deve, por isso, restringir-se às relações entre o escritor e a obra, pois, se assim fizer, a análise fornecerá apenas uma imagem da "unidade interna da obra", mas não "uma relação do mesmo tipo entre essa obra e o homem que a criou". O que se pode saber da estrutura psíquica de um autor morto há tanto tempo? A análise sociológica, contrariamente, consegue "destrinçar os elos necessários, vinculando-os a unidades coletivas cuja estruturação é muito mais fácil de apurar e elucidar" 5 .

A ênfase na singularidade do escritor cede lugar ao estudo sociológico, estrutural e genético, cuja "hipótese fundamental" pressupõe que "o caráter 
coletivo da criação literária provém do fato de as estruturas do universo da obra serem homólogas às estruturas mentais de certos grupos sociais" ${ }^{\text {. Os grupos }}$ estruturam na consciência de seus membros uma "resposta coerente" para as questões colocadas pelo mundo circundante. Essa coerência (ou visão do mundo) é elaborada pelo grupo social e atinge o máximo de articulação através da atividade imaginativa do escritor. A obra, assim, permite ao grupo entender mais claramente suas próprias idéias, pensamentos, sentimentos. Esta é a função da arte: favorecer a "tomada de consciência" do grupo social, explicitar num grau extremo a "estrutura significativa" que o próprio grupo elaborou de forma rudimentar para orientar o seu comportamento e a sua consciência.

Percebe-se aqui a diferença entre a abordagem psicanalítica da criação artística e a sociologia de Goldmann. Na interpretação de Freud, a criação artística é sublimação, é o resultado de um processo inconsciente que visa a compensar as frustrações libidinais do indivíduo fazendo aflorar aquilo que a consciência havia recalcado. Para Goldmann, contrariamente, a criação cultural é movida pela aspiração a um máximo de coerência, a um máximo de consciência possível. Essa intencionalidade não é a vingança do recalcado contra as censuras impostas pela consciência, mas o trabalho da própria consciência em busca do esclarecimento. A aspiração à coerência projeta um mais-além, uma antecipação da consciência em relação à imediatez. A perspectiva de futuro como dado integrante da vida social não existe para a psicanálise, prisioneira da eterna viagem ao passado, onde repousariam os segredos recalcados do homem. O passado explica o presente, $\mathrm{e}$ o futuro é uma dimensão inexistente. Goldmann diversas vezes repetiu que a única vez que Freud se referiu ao futuro foi ao nomear uma de suas obras de $O$ futuro de uma ilusão, mostrando, assim, que "essa ilusão não tem futuro"...

A coerência perseguida pelo artista e tomada pelo jovem Lukács e por Goldmann como critério para se avaliar a criação literária, remete a uma concepção de arte originária de Kant:

a definição da obra válida como tensão ultrapassada, num plano não conceitual, entre a extrema unidade e extrema riqueza, entre de uma parte a multiplicidade de um universo imaginário complexo e, de outra parte, a unidade e o rigor da criação estruturada ${ }^{7}$.

Goldmann aceita essa conceituação, porém com a retificação trazida por Hegel e pelo marxismo que vêem a unidade como decorrência de fatores sociais e históricos, e não algo atemporal. $\mathrm{O}$ estruturalismo genético, abre, assim, o caminho para se estudar a correspondência entre a unidade expressa pela criação cultural e a evolução da estrutura de uma determinada sociedade, a unidade entre as estruturas mentais ou categorias que organizam a consciência empírica dos grupos sociais e o universo imaginário criado pelo artista. Importante ressaltar aqui o papel de mediação atribuído às visões de mundo das classes sociais: são elas que se interpõem entre a vida econômica da sociedade e as criações culturais. 
O objetivo de uma sociologia da literatura é, portanto, a busca das homologias, o estudo das estruturas significativas presentes nos grupos sociais - o substrato social que confere unidade à obra literária. O projeto de Goldmann procura transpor para a literatura dois movimentos: o estudo da compreens ãa, isto é, da estrutura significativa imanente da obra e a explicação, a "inserção dessa estrutura, enquanto elemento constitutivo e funcional, numa estrutura imediatamente englobante [para] tornar inteligível a gênese da obra que se estuda"8.

Os textos goldmannianos, contudo, concentraram-se quase que exclusivamente no segundo momento. A busca da gênese das condições sociais que tornaram possível a obra de arte, o momento da explicação, consumiu a atenção de nosso autor. Suas incursões na vida literária e cultural procuraram oferecer um mapeamento das visões do mundo e dos grupos sociais que as estruturaram.

Goldmann objetivava realizar uma tipificação sistemática das visões do mundo, tarefa que requereria a contribuição de muitos pesquisadores. Sua militância no magistério levou-o a incentivar estudos coletivos e interdisciplinares nessa direção.

Ciências humanas e filosofia ${ }^{9}$, o livro mais divulgado de Goldmann no Brasil, apresenta um mapeamento detalhado das classes sociais e de suas visões do mundo expressas nas criações filosóficas e literárias do século XVII. Trata-se de um verdadeiro programa de trabalho e de um modelo para novas pesquisas.

Cinco classes comparecem nesse painel da cultura francesa nos tempos de Luís XIV: os grandes senhores, a nobreza da corte, a magistratura, o terceiro estado enriquecido e o povo miúdo (artesãos e camponeses).

Os grandes senhores (o autor refere-se basicamente aos duques) viviam uma situação incômoda. De um lado, assistiam impotentes às transformações sociais que lhes tiravam o poder; de outro, não podiam partilhar dos novos valores do mundo burguês ascendente, "mundo de egoísmo e de ambições mesquinhas". Por isso, diz Goldmann, a realidade é muito próxima para eles, "muito insuficiente e ao mesmo tempo muito potente para ser apreendida além do dado imediato, do acontecimento e da psicologia". É esse o contexto social das Memórias do Duque de Saint Simon e das Máximas do Duque de La Rochefoucauld.

A nobreza da corte vivia uma situação especial: uma vida de prazeres e de moral sexual livre, tanto para os homens como para as mulheres. A plena aceitação de uma ordem que os beneficiava traduz-se num epicurismo expresso na filosofia, por Gassendi e, no plano literário, por Molière. As peças deste autor revelam com clareza a posição da nobreza da corte e sua visão crítica sobre as demais classes. O avarento satiriza o burguês que faz do dinheiro a única finalidade da vida; $O$ tartufo volta-se contra o falso moralismo da igreja e a hipocrisia; $O$ misantropo revela a imagem que a corte fazia dos jansenistas e de sua vida solitária etc.

A magistratura, ou nobreza de toga, era constituída por setores de origem plebéia que ascenderam socialmente através do exercício das funções administrativas. O "pensamento trágico" é a expressão desse segmento sediado na provín- 
cia, em contato com o terceiro estado, de quem recebia influência, mas cujas idéias radicais não podia aceitar integralmente, já que sua fortuna se devia exclusivamente às funções exercidas e à fidelidade à monarquia. Essa situação contraditória propiciou a recusa ao mundo existente e o conseqüente isolamento social fatores que levaram ao desenvolvimento de uma visão trágica do mundo (Pascal, Racine).

\section{$O$ romance e a reificação}

Quando passa do século XVII para o mundo burguês plenamente constituído, Goldmann procura identificar as novas homologias que se estabelecem entre a "estrutura de troca da economia liberal" e a manifestação literária característica do período: o romance. $\mathrm{O}$ instrumental teórico de que lança mão para enfrentar esse desafio parte das reflexões de Marx sobre o fetichismo da mercadoria e de sua generalização para todas as esferas da vida social, tal como foi desenvolvida na teoria da reificação de Lukács em História e consciência de classe.

A outra fonte de Goldmann é a concepção hegeliana do romance como "epopéia do mundo burguês", retomada e desenvolvida por Lukács, em A teoria do romance e por René Girard, em Mesonge romantique et verité romanesque. Esses dois autores desenvolveram a contraposição entre a epopéia clássica e o romance, mostrando esse último como um gênero problemático em que o herói se debate com a tarefa impossível de tentar realizar valores num mundo hostil a eles. O caráter problemático atribuído ao romance traz uma modificação no enfoque goldmanniano: a homologia das estruturas continua sendo a referência básica, mas, agora, ela dispensa o papel mediador da visão do mundo das diversas classes sociais.

As duas fontes teóricas são mobilizadas por Goldmann para estudar os impasses do romance moderno.

N'O capital de Marx, o mundo burguês é distinguido das formas anteriores de produção pela predominância e universalização da forma mercadoria. $\mathrm{O}$ processo de mercantilização em curso dissimula o fato de que a produção é uma façanha humana, pois, ao assumir a forma de mercadoria, os produtos do trabalho humano ganham uma objetividade ilusória que, encobrindo as suas características sociais, apresenta-as de forma invertida como "características materiais e propriedades sociais inerentes aos produtos do trabalho" ${ }^{10}$. Assim, essas mercadorias (coisas), parecem enfeitiçadas: esquecida sua origem humana, social, elas parecem movimentar-se por conta própria e estabelecer relações "sociais" com as outras mercadorias, num movimento automático que parece prescindir da presença humana. Essa "ilusão fantasmagórica" foi chamada por Marx de fetichismo da mercadoria. No terceiro tomo d' O capital, Marx voltou ao tema em sua análise da "fórmula trinitária", a "santíssima trindade" por meio da qual os economistas procuravam explicar a origem da riqueza. Esta, segundo eles, provém de três generosas fontes: o capital, que propicia os lucros e os juros do capitalista; a terra, que garante a renda fundiária do proprietário rural; o traba- 
lho, que proporciona o salário, a renda do operário. Com tal procedimento ahistórico, os economistas colocavam no mesmo plano um elemento natural (a terra), com categorias sociais que só passaram a existir efetivamente no capitalismo, além de atribuírem equivalência entre o trabalho vivo executado pelo operariado e o trabalho morto, o trabalho objetivado que se transformou em capital.

Ao estudar a "fórmula trinitária", Marx observa a existência do fetichismo em todas as formações sociais em que há produção de mercadorias, vale dizer, também nas sociedades pré-capitalistas. Mas, no capitalismo, elas tornam-se uma“"categoria dominante". Outra característica importante, ao lado do fetichismo, do enfeitiçamento das mercadorias que ganham uma objetividade fantasmagórica e passam a estabelecer relações "humanas" entre si, é o processo correlato de reificação das relações entre os homens. Assim, de um lado, "personificação" das coisas e, de outro, "reificação" das relações de produção (os homens relacionam-se no mercado como portadores, suportes de mercadorias força de trabalho versus dinheiro, salário).

História e consciência de classe trouxe para o primeiro plano a discussão sobre reificação, dando novos contornos ao tema. Em Marx, com vimos, a "ilusão fantasmagórica" já se fazia presente, embrionariamente, nas formações précapitalistas. Para Lukács, "a questão do fetichismo é uma questão especifica da nossa época e do capitalismo moderno" 1 . O tráfico mercantil já existia anteriormente, mas no capitalismo a dominação da forma mercadoria produz um salto qualitativo, passando a "influenciar toda a vida" da sociedade. A mercantilização, agora, penetra "o conjunto das manifestações vitais da sociedade", transformando-a à sua "imagem". Com isso, Lukács faz da reificação "o problema central, estrutural da sociedade capitalista em todas as suas manifestações vitais". O seu empenho, portanto, estará voltado para "descobrir na estrutura da relação mercantil o protótipo de todas as formas de objetividade e de todas as formas correspondentes de subjetividade da sociedade burguesa" ${ }^{2}$. O estudo dessas últimas formas (as subjetivas) é a contribuição original de Lukács ao marxismo, de enorme influência no pensamento social do século XX.

Goldmann, a seu modo, retoma as análises de Lukács para explorar essa correlação entre objetividade e subjetividade, instaurada pela reificação, aplicando-a ao estudo da criação cultural e literária, áreas não trabalhadas naquele texto lukacsiano.

A reificação, entendida pelo nosso autor como um "processo psicológico permanente", afirma-se cada vez com mais intensidade. O romance, produto do mundo burguês, mantém uma relação de "rigorosa homologia" com as principais fases da estrutura econômica dessa formação social.

A primeira fase, marcada pela economia liberal, estende-se até o início do século XX. A expressão ideológica dominante é o liberalismo e a apologia do individualismo e da livre iniciativa. O indivíduo, portanto, foi alçado ao centro da vida social. Esta, contudo, começava a sofrer os efeitos perturbadores da reificação. 
A literatura, nesse contexto, expressa o desconforto perante a reificação nascente. No mundo desumanizado, os personagens se debatem em busca de um sentido para a existência. O "herói problemático" faz a sua aparição, inicialmente em Dom Quixote e, depois, em Stendhal, Flaubert e Goethe. Romance, aqui, é crônica social: é estudo das relações entre os personagens problemáticos e os contextos sociais opressivos: essas relações nos contam a tentativa de realização de valores autênticos num mundo hostil aos valores; portanto, busca degradada de valores por personagens desadaptados - busca condenada ao fracasso, que assinala o caráter precário e problemático da forma romance.

$\mathrm{Na}$ fase seguinte, a imperialista, a formação dos monopólios suprime a livre concorrência e a iniciativa individual, produzindo uma modificação substantiva na ordem burguesa. Segundo Goldmann, o período assinala "a supressão de toda a importância essencial do indivíduo e da vida individual, no seio das estruturas econômicas e, a partir destas, no conjunto da vida social" ${ }^{13}$. O romance, acompanhando as metamorfoses da estrutura social, sofre uma drástica modificação formal. O "herói problemático" sai de cena e seu lugar é ocupado pelo processo de dissolução do personagem, tais como aparece em Kafka, Joyce, Musil e em algumas obras do existencialismo francês ( $A$ náusea de Sartre e Oestrangeiro de Camus).

Finalmente, o período posterior à Segunda Guerra Mundial é caracterizado pela intervenção do Estado na economia visando a controlar as crises cíclicas do capitalismo. A nova fase, chamada de "capitalismo de organização", inaugura um longo ciclo de estabilidade e expansão econômica, produzindo a impressão de uma ordem auto-regulada, uma segunda natureza, destinada a se perpetuar. A expressão literária do período é o nouveau roman, que registra a vitória definitiva da reificação, o triunfo acachapante das coisas sobre os homens.

O novo momento, afirma Goldmann, não se exprime totalmente em todos os romances do período. Os de Nathalie Sarraute, por exemplo, ainda estariam presos à problemática psicológica: mesmo quando utiliza quarenta páginas (quarenta páginas!) para descrever a maçaneta de uma porta em Planetário, a descrição permanece subordinada às reações psicológicas dos personagens, tal como pregava o realismo crítico em seu empenho de subsumir a descrição à narração, à ação dos personagens. A figura central da nova fase, em que o romance adquire uma forma homóloga às estruturas do mundo totalmente reificado, é RobbeGrillet. Os romances (e filmes) desse autor ressaltam a coisificação de uma sociedade auto-regulada na qual os objetos postos em primeiro plano ganham uma total autonomia em relação aos homens, estes reduzidos a espectadores passivos que se limitam a contemplar a realidade. Nesse mundo imóvel, não há lugar nem para a ação nem para a intencionalidade: a descrição detalhista e obsessiva dos objetos reproduz, no plano literário, a fixidez das estruturas sociais e a total desimportância dos homens.

Um bom exemplo é La jalousie ${ }^{14}$, romance que trata de um tema tradicionalmente vinculado às inquietações subjetivas, já que para sentir ciúme nem sempre 
é necessário a existência objetiva de indícios, pistas e referências seguras. Justamente esse tema, tão recorrente na literatura, é enfocado por Robbe-Grillet de modo nada convencional: um narrador distanciado (o marido ciumento), como uma câmara fotográfica, retrata com um máximo de distanciamento, frieza e indiferença, cenas que se repetem - sem deter-se em nenhuma caracterização psicológica ou referir-se aos pensamentos e estados de espírito dos personagens igualados às coisas. A supressão dos personagens, a ausência de ação, a ruptura com qualquer linearidade temporal, marcam esse livro perturbador. O único sentimento que tudo move - o ciúme do marido - totalmente sublimado, transfigura-se em sua obsessão de registrar, sem nunca comentar, as cenas imóveis que nos apresenta. Goldmann afirma ser esse romance

o verdadeiro protocolo da reificação de um mundo no qual somente as coisas agem, onde o tempo humano desapareceu e onde o próprio homem tornou-se um simples espectador reduzido ao estado mais abstrato: um olho que regis$\operatorname{tra}^{15}$.

Robbe-Grillet, em seus ensaios teóricos, procurou sempre afirmar o caráter realista de seus romances. A defesa do realismo, diz ele, é uma constante na história literária. Cada nova escola literária, voltou-se sempre contra as anteriores, invocando o realismo:

era a palavra de ordem dos românticos contra os clássicos, depois a dos naturalistas contra os românticos; e os próprios surrealistas afirmavam só se preocupar com o mundo real. [...]. Se não se entendem é porque cada um tem idéias diferentes sobre a realidade ${ }^{16}$.

As transformações na sociedade explicariam o surgimento e a caducidade dos modos de se entender a realidade. O nouveau roman, segundo Robbe-Grillet, é uma tomada de consciência, uma afirmação da impossibilidade de retratar o real seguindo o velho cânon do realismo clássico. Aliás, ele não se preocupa mais com a verossimilhança, e nem com as tentativas de utilizar a literatura para desvendar sentidos exteriores a ela; o foco da narração deve ser a "significação imediata das coisas". O novo romance, diz, "não exprime, procura. E aquilo que procura é ele mesmo" 17 . Voltamos aos ensinamentos de Flaubert: "construir alguma coisa a partir do nada, que fica em pé sem ter que se apoiar seja no que for do mundo exterior à obra" ${ }^{18}$.

O fechamento da linguagem sobre si mesma, a ruptura com o referente, eram idéias que aproximavam, naquele período histórico, as teorias estruturalistas e os romances de Robbe-Grillet. A idéias postas em circulação pelo estruturalismo são as mesmas do nouveau roman: a ausência de historicidade, o descentramento do sujeito e a morte do homem, seja ele o personagem (reduzido a "efeito" ou "suporte" das estruturas - e por isso, igualado às coisas), ou o próprio autor (já que agora quem "fala" é a escritura). Uma literatura reduzida ao fechamento da linguagem sobre si mesma expressa, assim, o espírito de uma época hegemonizada pelo estruturalismo em guerra contra a tradição humanista ${ }^{19}$. 
Goldmann não se ateve a essa afinidade, limitando-se a ver, com entusiasmo, na literatura de Robbe-Grillet a manifestação de realismo adequada à era do capitalismo de organização. E por realismo literário Goldmann entende a "criação de um mundo cuja estrutura é análoga à estrutura essencial da realidade social" 20 .

Os estudos literários goldmannianos sobre o nouveau roman, feitos a partir da teoria da reificação, marcam uma ruptura com toda a teoria da consciência de classe que até então lhe servira de suporte. A consciência de classe, ponto organizador das estruturas significativas, perdeu a antiga função explicativa. $\mathrm{O}$ arcabouço teórico laboriosamente montado para fundar uma sociologia da cultura esbarra na forma problemática do romance num mundo governado pelo movimento autônomo dos objetos. A reificação venceu definitivamente. Se a classe social não pode mais expressar-se, se sua consciência está irremediavelmente atrofiada, quem "fala" através da literatura?

\section{Sujeito, classe, gênero problemáticos}

A questão do sujeito da criação cultural, desde o começo, estava marcada por uma indefinição. Apoiando-se em Lukács, Goldmann trouxe para o primeiro plano as classes sociais e sua consciência. Lukács, contudo, foi cauteloso ao discorrer sobre a formação das classes. Para ele, só se pode falar na divisão da sociedade em classes com o advento do capitalismo, momento em que a exploração econômica, libertada dos véus da religião e da política, exerce soberana a sua dominação. É essa visibilidade da economia que tornou possível a consciência de classe. Goldmann, contrariamente, utiliza a teoria da consciência de classe de Lukács para analisar as manifestações artísticas do século XVII ${ }^{21}$. E, como é impossível detectar aí a existência de classes plenamente configuradas, Goldmann, recorre a expressões imprecisas, como "grupos sociais específicos" e "sujeito transindividual”.

De qualquer modo, há uma diferença básica a separar a concepção ontológica das classes sociais, presentes na obra de Marx, das incursões sociológicas goldmannianas. Estas restringem-se à busca de um equivalente sociológico para a produção literária. É como se as classes fossem configurações estáticas e autosuficientes e a criação artística um reflexo passivo e imediato. Desse modo, podese falar em" "homologia das estruturas", dispensando o papel ativo da consciência do artista e qualquer outra mediação. Frederic Jamenson, a propósito, observa:

o que distingue a noção marxista de classe da noção sociológica é que, para a primeira, a classe é precisamente um conceito diferencial, que cada classe é, ao mesmo tempo, um modo de se relacionar com as outras e de recusá-las. Quaisquer quer que sejam seus pressupostos filosóficos, a visão sociológica é formalmente errada, na medida em que nos permite pensar as classes individuais numa espécie de isolamento mútuo, com a separação quase física dos grupos sociais na cidade ou no campo, ou como "culturas" de algum modo independentes umas das outras e que se desenvolvem de maneira autônoma: pois a 
noção da classe ou do grupo social isolado é uma hipóstase exatamente como o é a noção do indivíduo solitário na filosofia do século XVIII ${ }^{22}$.

Ao afirmar a vitória final da reificação no chamado "capitalismo de organização", Goldmann afastou-se também das idéias de Marx e Lukács que lhe serviram de ponto de partida para analisar as metamorfoses do romance.

Em Marx, a autonomia das coisas não passava de uma ilusão, se bem que ilusão necessária a uma ordem social na qual a exploração do homem pelo homem apóia-se exclusivamente na coerção econômica, dispensando a presença de outros fatores de legitimação (políticos, religiosos etc.), presentes nas formações sociais anteriores. A economia política clássica foi criticada por ser uma ideologia empenhada em duplicar essa aparência enganosa, tomando-a como um dado natural, a-histórico e, dessa forma, elidindo a existência do trabalho humano como gênese da criação da riqueza. Lukács, a propósito, observou que Marx, em oposição às mistificações da economia política, promoveu'“a dissolução de todas as objetividades reificadas da vida econômica e social em relações inter-humanas"23.

Constatando a extensão do processo de reificação na sociedade moderna, Goldmann ateve-se à "ilusão fantasmagórica" e tirou de cena as classes sociais e suas manifestações de consciência. No século XVII, quando as classes ainda não estavam configuradas, a teoria lukacsiana servia-lhe de referência; no século XX, ao contrário, quando elas já se constituíram plenamente, Goldmann estuda o advento do nouveau roman sem referir-se a nenhuma classe social ${ }^{24}$. Aqui, estamos em pleno mecanicismo: literatura é reflexo imediato que dispensa a mediação das classes sociais e de suas lutas; o próprio autor, em seu desenraizamento social, transformou-se num mero fotógrafo de uma realidade estranha que não lhe diz respeito.

Outra questão a ser analisada é a concepção do romance como epopéia do mundo burguês. A pertinência da tese hegeliana foi contestada por Bakhtin para quem o romance não é a retomada da epopéia, mas a consciência de uma realidade nova. Por isso, o romance é o único gênero não acabado, em devir, que desconhece qualquer cânon. Ele formou-se em oposição à epopéia, no "processo de destruição da distância épica, no processo de familiarização cômica do mundo e do homem, no abaixamento do objeto da representação artística ao nível de uma realidade atual, inacabada e fluida" 25 .

Ao retomar a tese hegeliana, Goldmann incorporou a idealização da epopéia e o conseqüente rebaixamento do romance. Por sua vez, esse procedimento se fez acompanhar do culto à antiga comunidade perdida, da totalidade harmoniosa que se estilhaçou no mundo moderno, mundo da inautenticidade, tal como foi definido por Heidegger ou Mounier. A idealização da epopéia e da comunidade harmoniosa, no jovem Lukács, havia sido uma datada reação romântica à afirmação de uma sociedade capitalista em vias de desenvolvimento e aos seus produtos culturais - uma posição regressiva, portanto. Contra o inevitável pro- 
gresso, Lukács figurava a oposição insuperável entre o indivíduo e o mundo. Esse é o contexto do herói problemático, condenado ao fracasso, e do próprio romance, um gênero destinado ao desaparecimento no mundo reificado.

Goldmann, décadas depois, retomou as idéias de $A$ alma e as formas e de $A$ teoria do romance sem modificações substantivas. Ferenc Fehér, ao estudar as perspectivas do gênero romance, criticou duramente as posições de Goldmann ${ }^{26}$, a partir das reflexões do Lukács marxista de Escritos de $\mathrm{Moscou}^{27}$. Para Fehér, a glorificação da epopéia e o conseqüente rebaixamento do romance é um equívoco. O romance não é um gênero problemático, mas ambivalente. Ele é fruto da sociedade burguesa e, como tal, sofre essa limitação; mas, essa sociedade, ao contrário do mundo antigo, é estruturada sobre formas puramente sociais, e não mais naturais. Os laços de sangue, as relações de parentesco, a religião etc. cederam lugar nessa nova realidade onde tudo é visto como resultado da ação humana. Com isso, pôde-se firmar, enfim, a consciência do gênero humano, transcendendo todos os limites tribais, nacionais e religiosos. A nova sociedade, apesar de todas as suas mazelas, significou um passo à frente no processo de emancipação humana. O herói moderno, portanto, não deve ser visto como se vivesse numa total incompatibilidade com o mundo, sem solução possível. Ele é um ser que escolhe entre alternativas, que responde aos desafios da realidade, ora em conformidade com os limites do mundo burguês, ora em consonância com as necessidades do gênero humano e do processo de emancipação. Ao contrário da epopéia, o herói do romance é alguém empenhado em "construir, para seu uso, um universo - universo ilusório ou real" 28 . Enquanto o herói da epopéia cumpria um destino que lhe foipredestinado, no romance há uma "orientação para o futuro", que transfere a responsabilidade para as ações dos personagens. O caráter aberto do romance é uma característica que aproxima, de certo modo, Ferenc Fehér de Bakhtin. Nos dois autores há uma valorização do romance. Para eles, trata-se de um gênero superior à epopéia, pois volta-se à desfetichização do mundo. $O$ romance moderno é um gênero que não está condenado a desaparecer, mas, sim, em permanente transformação formal para enfrentar os novos desafios e resgatar a humanitas ameaçada pela reificação.

Ao criticar aqueles que vêem o romance como uma forma artística inferior condenada ao desaparecimento, Fehér volta-se contra a "homologia das estruturas" de Goldmann:

[...] o romance é justamente não homólogo à estrutura do sistema de mercado, porque atrás da estrutura dominante deste, é verdade que numa medida decrescente, emergem à superfície os "autênticos" valores humanos, aqueles que nos dirigem para o enriquecimento da "substância humana"29.

Vitória final da reificação e completa homologia entre as estruturas do romance sem sujeito e a realidade depurada de todos os seus vestígios humanos: o ponto de chegada da sociologia do romance de Goldmann está em pleno desacordo com aquela tradição dialética e humanista reivindicada pela melhor tradi- 
ção marxista. A "lógica do conteúdo", substituída pelo culto à forma e à busca das simetrias, assinala uma concessão às pretensões do estruturalismo então em voga.

Talvez se possa afirmar que o nouveau roman é um "romance de tese" e não o atestado de óbito da práxis humana transferido para a figuração literária. $\mathrm{O}$ pessimismo daqueles tempos em que a história surgia estagnada nos textos estruturalistas, embora continuasse se movendo, envolveu o espírito inquieto de Goldmann, sempre atento para captar os sinais emanados pela criação cultural. Mas, hoje sabemos, o nouveau roman foi apenas um capítulo, e não dos mais brilhantes, das inúmeras tentativas experimentais de renovação daquele gênero considerado erroneamente como "problemático".

\section{As "duas epistemologias" de Goldmann}

A guinada teórica de Goldmann trouxe uma visível contradição para o interior de sua obra - dividida entre a ênfase na "consciência possível", como mediação entre a obra e a estrutura social e a admissão do triunfo definitivo da reificação, que colocou em crise o papel do indivíduo e das classes sociais na sociedade mercantil e, por extensão, do personagem do romance burguês, o "herói problemático". Um dos discípulos de Goldmann, Jacques Lenhardt constatou a contradição e a existência de duas epistemologias em sua obra.

Após o movimento de maio de 1968, contudo, Goldmann voltou a falar em "consciência possível”, mas manteve a sua adesão ao estruturalismo-genético. O último de seus livros, publicado em 1971, foi A criação cultural na sociedade moderna. A saga do "herói problemático" lukacsiano reaparece, timidamente, no enquadramento histórico proposto.

Inicialmente, Goldmann retoma a fase do capitalismo concorrencial, aquela em que o herói expressava a afirmação do indivíduo e de seus valores, num momento em que a criação literária exercia um papel abertamente crítico ao retratar os embates do personagem com um mundo que rejeita os seus valores; depois, na fase imperialista, a literatura abandonou o tema das possibilidades do personagem para enfocar os seus limites - a morte, quando o autor era filiado ao existencialismo; finalmente, no capitalismo de organização, efetivou-se o "encolhimento da consciência", e a literatura deixou de ser o "processo de estruturação de uma consciência coletiva", o ponto de encontro do indivíduo (o escritor) e a vida do grupo social. A consciência agora tende a tornar-se "mero reflexo" 30 e os valores transindividuais desaparecem, bem como a angústia existencial que perseguia o "ser-lançado-no-mundo", cujo horizonte na filosofia heideggeriana seria a morte, a consciência da finitude como horizonte do ser. A homologia entre a obra e a sociedade "não passa mais através da consciência de um grupo qualquer"31. Goldmann, apoiando-se nos trabalhos de Riesman e Habermas constata o desaparecimento da opinião pública, que para o artista sempre havia sido "uma espécie de solo nutriente intermediário entre a sociedade global e a criação cultural" 32 . 
Apesar disso, duas formas de reação cultural ainda sobreviveriam. A primeira delas, através da revolução na forma romanesca, tal como praticada por Robbe-Grillet. O nouveau roman, portanto, não é mais interpretado como constatação da reificação triunfante, mas sim como revolta. Mas essa literatura, ao contrário do realismo crítico, encontra-se impossibilitada de elaborar uma história capaz de ser percebida de modo imediato pelo leitor, já que a realidade, sob a reificação, apresenta-se invertida. Ao configurar a realidade sob o ângulo das coisas, a literatura tornou-se incompreensível para o leitor comum, uma atividade acessível apenas para os críticos. Além disso, o abandono do "herói problemático" cedeu lugar à representação de "um universo estável, equilibrado, mas rigorosamente a-humano" 33 .

A segunda forma de revolta é a do "pensamento oposicionista" que traz o conflito social para o centro da figuração literária. Mas, aqui, as dificuldades são também imensas: não se pode mais escrever a história de um indivíduo, já que ele "não tem realidade essencial", e nem se pode falar das forças de contestação, "quando estas não existem ou estão desaparecendo" 34 . Tais dificuldades bloqueiam a criação cultural na atualidade. Apenas uma exceção é lembrada: Jean Genet. Tanto ele como Sartre, contudo, para abordar os temas da revolta, precisaram abandonar a literatura e refugiar-se no teatro. No caso específico de Genet ocorre uma outra modificação substancial: o personagem individual cede lugar aos personagens coletivos. Por isso, Genet é figura solitária ao reafirmar a dimensão do possível e a ultrapassagem da ordem. Seus primeiros textos, observa Goldmann,

foram escritos na perspectiva de um sujeito coletivo bem preciso: os outsiders, os pequenos ladrões, as prostitutas e todo o mundo marginal em relação à sociedade; eles exprimem a visão, a perspectiva deste grupo social. [...]. Todavia, este grupo não elabora valores próprios ${ }^{35}$.

O recurso à visão do mundo e a concepção da literatura como "estruturação das categorias mentais do grupo", fazem, assim, suas reaparições no interior da sociedade administrada. Mas são em número muito restrito os exemplos citados por Goldmann. No caso do Malraux de $A$ condição humana, trata-se de um grupo socialmente heterogêneo que só se constituiu uma comunidade através do engajamento no processo revolucionário - uma aposta, para usarmos uma expressão cara a Goldmann. Em Genet, como vimos, trata-se também de um grupo heterogêneo, porém incapaz de afirmar valores, e que não propende "para uma visão global do homem" - o objetivo da boa literatura, segundo pensava Goldmann.

Seja como for, a relação entre obra artística e classe social permanece num esfera indefinida e vaga, criando dificuldades para a construção de uma sociologia da literatura. 
1 Na vasta produção voltada para a literatura destacam-se os seguintes trabalhos: Sociologia do romance, Rio de Janeiro, Paz e Terra, 1967; "Structuralisme génétique en sociologie de la littérature", em VV. AA. Le structuralisme génétique. L'oeuvre et l'influence de Lucien Goldmann, Paris, Denoël/ Gonthier, 1997; "Máterialisme dialectique et histoire de la littérature"; "Le concept de structure significative en histoire de la littérature", em Recherches dialectiques, Paris, Gallimard, 1959; "Critique et dogmatisme dans la création littéraire"; "La sociologie de la littérature: statut et problèmes de méthode"; "Le subject de la création culturelle", em Marxisme et sciences bumaines, Paris, Gallimard, 1970; Structures mentales et création culturelle, Paris, Anthropos, 1971; A criação cultural na sociedade moderna, São Paulo, Difusão Européia do Livro, 1972.

2 Sami Naïr, “Forme et subjet dans la création culturelle”, em VV. AA., op. cit., pp. 5253.

3 L. Goldmann, "Structuralisme génétique en sociologie de la littérature", em V.V. A.A., op. cit., p. 21.

4 Cf. L. Goldmann, "La sociologie de la littérature: statut et problèmes de méthode", em Marxisme et sciences humaines, op. cit., p. 55.

5 L. Goldmann, "O método estruturalista genético na história da literatura”, em Sociologia do Romance, op. cit., p. 206.

6 Idem, p. 208.

7 L. Goldmann, "Critique et dogmatisme dans la création littéraire”, em Marxisme et sciences humaines, op. cit., pp. 46-47.

8 L. Goldmann, "La sociologie de la littérature: statut et problèmes de méthode", em Marxisme et sciences humanaines, op. cit., p. 66.

9 Cf. Ciências humanas e filosofia, $10^{a}$ ed., São Paulo, Difusão Européia do Livro, 1986, especialmente pp. 90-93.

10 K. Marx, O capital, livro I, Rio de Janeiro, Civilização Brasileira, 1968, p. 80.

11 G. Lukács, História e consciência de classe, Porto, Publicações Escorpião, 1974, p. 98.

12 Idem, pp. 97-99.

13 L. Goldmann, op. cit., 1967, p. 176.

14 Há tradução brasileira: O ciúme, Rio de Janeiro, Nova Fronteira, 1986.

15 Lucien Goldmann, Recherches dialectiques, Paris, Gallimard, 1959, p. 92.

16 Alain Robbe-Grillet, Por um novo romance, São Paulo, Documentos, 1969, p. 105.

17 Idem, p. 107.

18 Idem, p. 108.

19 François Dosse assinalou a confluência do estruturalismo tanto com os modelos formais das ciências exatas como da "nova sensibilidade literária". Sobre esse último ponto observou: "reencontra-se a temática estrutural em ação nos princípios fundadores donouveau roman: a mesma colocação do sujeito à distância, com a exclusão do personagem romanesco clássico, o mesmo privilégio concedido ao espaço que se desenrola através das diversas configurações das coisas localizadas pelo olhar do roman- 
cista, o mesmo desafio em face da temporalidade em sua dialética, a qual é substituída por um tempo suspenso, um presente estático que se dissolve ao desvendar-se". Cf. História do estruturalismo, vol. 2, São Paulo, Ensaio, 1994, p. 231.

20 L. Goldmann, op. cit., 1967, p. 195.

21 Fato que não escapou ao olhar atento de Agnes Heller: "Contrariamente a Lukács, Goldmann aplica a noção de consciência de classe ou grupo quase exclusivamente a sociedades precapitalistas. A objetivação analisada por ele e relacionada a diferentes grupos sociais são aquelas das sociedades precapitalistas, e nenhuma delas reflete primordial ou diretamente a base econômica da sociedade como um todo". "Role of the intellectual in Lukács and Goldmann”, em Agnes Heller e Ferenc Fehér, The Grandeur and Twilight of Radical Universalism, New Brunswick, New Jersey, Transaction Publishers, 1991, p. 369.

22 Frederic Jamenson, Marxismo e forma, São Paulo, Hucitec, 1985, p. 289.

23 G. Lukács, op. cit., 1974, p. 62.

24 Um discípulo de Goldmann, Jacques Leenhardt, estudou detidamente $O$ ciúme de Robbe-Grillet. Procurando ir além das idéias do mestre, empenhou-se em desvelar as bases sociais do nouveau roman. A visão do mundo expressa no Nouveau Roman apontaria para "os primeiros lineamentos de uma ideologia que teria por função, como o grupo ou a fração de classe tecnocrática no plano da produção, transcender tanto os antagnismos de classe, simbolizados pelos pensamento socialista, como o individualismo”. Cf. Jacques Leenhardt, Lectura politica de la novela, México, Siglo Veintiuno, 1975 , p. 38.

25 Mikhail Bakhtin, Questões de literatura e estética, São Paulo, Unesp/ Hucitec, 1988, p. 427.

26 Cf. Ferenc Fehér, O romance está morrendo? Rio de Janeiro, Paz e Terra, 1972.

27 Cf. G. Lukács, Écrits de Moscou, Paris, Sociales, 1974. Os dois principais ensaios do livro foram traduzidos para o português: "O romance como epopéia burguesa", na revista Ad hominem, n. 1, São Paulo, 1999; en“Nota sobre o romance”, em José Paulo Netto (org.), Lukács, São Paulo, Ática, 1981 (Grandes Cientistas Sociais).

28 Idem, p. 16.

29 Idem, p. 49.

30 L. Goldmann, A criação cultural na sociedade moderna, São Paulo, Difusão Européia do Livro, 1972, p. 66.

31 Idem, p. 68.

32 Idem, p. 74.

33 Idem, p. 76.

34 Idem, p. 47.

35 Idem, p. 90. 


\section{Referências}

BAKHTIN, M. Questões de literatura e estética. São Paulo, Unesp/ Hucitec, 1988.

DOSSE, F. História do estruturalismo, vol. II. São Paulo, Ensaio, 1994.

FEHER, F. O romance está morrendo? Rio de Janeiro, Paz e Terra, 1972.

GOLDMANN, L. Sociologia do romance. Rio de Janeiro, Paz e Terra, 1967.

. Recherches dialectiques. Paris, Gallimard, 1959.

. Marxisme et sciences humaines. Paris, Gallimard, 1970.

. Structures mentales et création culturelle. Paris, Antrophos, 1971.

A criação cultural na sociedade moderna. São Paulo, Difusão Européia do Livro, 1972. 1986

Ciências humanas e filosofia. 10 $0^{\mathfrak{a}}$ ed., São Paulo, Difusão Européia do Livro,

HELLER, A. "Role of the Intellectual in Lukács and Goldmann". Em HELLER, A. e FERENC, F. The Grandeur and Twilight of Radical Universalism. New Brunswick, New Jersey, Transaction Publishers, 1991.

JAMESON, F. Marxismo e forma. São Paulo, Hucitec, 1985.

LEENHARDT, J. Lectura politica de la novela. México, Siglo XXI, 1975.

LUKÁCS, G. História e consciência de classe. Porto, Publicações Escorpião, 1974. . Écrits de Moscou. Paris, Sociales, 1974.

. "O romance como epopéia burguesa”. Ad Hominem, n. 1, São Paulo, 1999.

“Nota sobre o romance”. Em NETTO, José Paulo (org.). Lukács. São Paulo, Ática, 1981 (Grandes Cientistas Sociais).

MARX, K., O capital, livro I. Rio de Janeiro, Civilização Brasileira, 1968.

ROBBE-GRILLET, A. O ciume. Rio de Janeiro, Nova Fronteira, 1986.

. Por um novo romance. São Paulo, Documentos, 1969.

VV. AA. Le structuralisme génétique. L'oeuvre et l'influence de Lucien Goldmann. Paris, Denöel/ Gonthier, 1997.

RESUMO - os ESTUdos literários de Lucien Goldmann conheceram duas fases distintas. Na primeira, apoiando-se principalmente nas contribuições do jovem Lukács ( $A$ alma e as formas e Teoria do romance), Goldmann buscou estabelecer uma homologia entre a forma romanesca e a vida social e, ainda, recorrendo à História e consciência de classe, procurou dar um tratamento historicista e dialético àqueles textos juvenis do pensador húngaro, ao interpretar a literatura como expressão articulada das "visões do mundo" das diversas classes e grupos sociais. Numa segunda fase, marcada pelo pessimismo e pela influência das idéias estruturalistas, então em voga, os ensaios goldmannianos afastaram-se da busca de mediações entre a obra e a vida social. Surpreendido pelo vendaval de 1968, Goldmann empreendeu um movimento autocrítico, interrompido pela morte prematura em 1970.

Palavras-chave: Literatura; marxismo; estruturalismo; sociologia do romance. 
ABSTRACT-LUCIEn Goldmann's literary studies fall into two distinct phases. In the first, relying mainly on contributions of the young Lukács (Soul and form and The theory of the novel), Goldmann sought to establish a homology between the novelistic form and social life. Moreover, falling back on History and class-consciousness, he sought to give a historicist and dialectical treatment to the youthful texts of the Hungarian thinker by interpreting literature as an articulate expression of the "views of the world" held by various classes and social groups. In the second phase, marked by pessimism and the influence of structuralist ideas, then in vogue, Goldmann's essays ceased to seek mediations between the written work and social life. Taken by surprise by the maelstrom of 1968, Goldmann engaged himself in a self-critical movement, interrupted by his premature death in 1970 .

Key-words: Literature; marxism; structuralism; sociology of the novel.

Celso Frederico é professor da Escola de Comunicações e Artes da USP e bolsista do CNPq. No segundo semestre de 2003, pesquisou os arquivos de Goldmann em Paris graças a uma bolsa concedida pelo convênio Capes-Cofecub. @ - celsof@usp.br

Recebido em 19/4/2004 e aceito em 13/9/2004. 